\title{
Lindy Grant and Richard Mortimer, eds. Westminster Abbey: The Cosmati Pavements
}

Courtauld Institute Research Papers, 3.

Ashgate Publishing, 2002

Reviewed by John Sharp

In volume 1 of the Nexus Network Journal (1999), I wrote about a conference held on the Cosmati pavements in Westminster Abbey in London in November 1998 [Sharp 1999]. The papers presented at the conference have now been published as Courtauld Research Papers no 3 with the title Westminster Abbey: The Cosmati Pavements, edited by Lindy Grant and Richard Mortimer.

Although Cosmati pavements are usually associated with Italy, there are two important ones in Westminster Abbey in London. The Great Pavement in front of the altar is described in Richard Foster's Patterns of Thought [1991], a detailed study, but these papers supplement that study many ways. The pavement around the tomb of Edward the Confessor and the Cosmati work on the tomb itself are given a higher prominence in these papers. The papers are important because they because the pavements are not simply decoration or a show of wealth, but because their symbolism and position in the history and politics of the time is crucial to appreciating them. The ideas put forward suggest that more could be done in researching and writing about the importance of other great buildings in history so that they can be appreciated more than just marvels of architecture.

In my original review I said that was I amazed by how complex and different it was compared with the Cosmati pavements I had seen in Italy and that the political and symbolic background seemed more intriguing. But if I look at Kim Williams's excellent book Italian Pavements [1997] by contrast, I can only think what lies behind them in the life and politics of the times in which they were constructed and what remains unknown about them.

\section{Contents}

The book is a modest 140 pages with some general photographs together with a photograph and measured drawing of the Great Pavement. Most papers contain a wealth of references.

One cannot expect the book to provide the thrill of looking at and walking on the pavement that I wrote about in the review of the conference, but it does provide a good record of that day. The papers are well written in a way which makes it an easy read rather than a dry scholarly document, not least because of the wide range of topics covered. Since they are independent, I will discuss them individually according to the contents:

- "Introduction," by Lindy Grant

- "The luxury pavement in England before Westminster," by Christopher Norton

- "Westminster Abbey and the Cosmati pavements in politics, 1258-1269," by David Carpenter 
- "The context and fabric of the Westminster Abbey Sanctuary pavement," by Richard Foster

- "The condition and conservation of the Cosmati pavements at Westminster Abbey," by Nicholas Durnan

- "The inscriptions in the Sanctuary pavement at Westminster," by David Howlett

- "The Cosmati and romanitas in England: an overview," by Paul Binski

\section{"Introduction," by Lindy Grant}

The Great Pavement of Westminster Abbey was laid down by Italian craftsmen in 1268 for Henry III, so it is not surprising, as Lindy Grant says in her introduction, that it has been written about many times in its history. The wide range of books and papers included in the references are testament to this. But like all scholarship, it is necessary to revise these views in the light of modern technology and historical discovery. Such new information also raises many new questions. She also highlights that the papers bring the pavements to life, since various key themes emerge from power and patronage to the liturgical significance. Despite so much being known, she ends by saying that the exact date, "the context, the interpretation and the meaning of the Westminster Cosmati pavements remain unresolved, topics for future work and discussion."

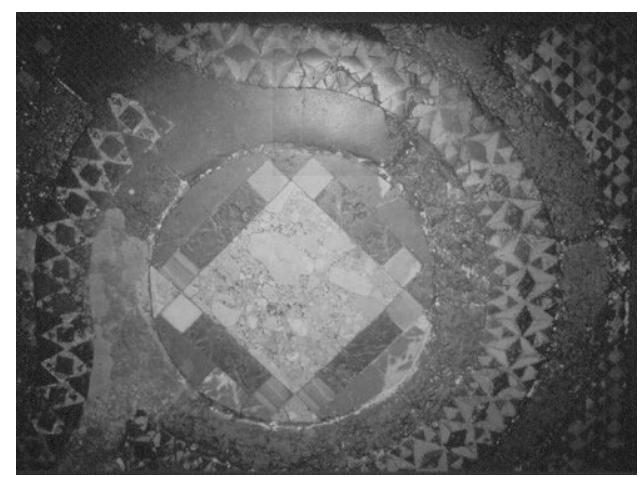

Detail of the Great Pavement. Photograph (C) John Sharp

\section{"The Luxury Pavement in England before Westminster," by Christopher Norton}

This paper sets the context of the pavements in the construction of others in Northern Europe. This is a matter of available materials and also of their survival and contrasts them with those in Italy in particular. He begins with a quote from James Peller Malcolm [1803] which he says would not be expressed in the same way today, although we would agree with the sentiment:

We tread on the wreck of the most glorious work in England; venerable through age, costly in its materials and invaluable for its workmanship. What must have been the glories of this holy place soon after the completion of the church!

Although it is not in its former glory, and not at a state of repair of many of the glorious Italian pavements drawn by Kim Williams [1997], it is still something to marvel at. More so, since as Christopher Norton points out, when you go around English (as opposed to British) chapels, cathedrals and abbeys, you notice not the marble pavements of the churches in Italy, but the lead glazed ceramic tiles characteristic of north western Europe and "England was unsurpassed in its in the quality, variety and quality of its tiled pavements". He describes how this covers the whole 
country from a chapel in Durham Castle in north eastern England down to Canterbury in the south. This aesthetic decoration is not always in evidence since the pavement around the shrine of St Cuthbert in Durham Cathedral not far from the Castle is made of irregular sandstone slabs.

The history of England is one of change, and much may have been lost. When Henry VIII wanted a divorce and broke the church away from Rome in the sixteenth century, he dissolved the monastic system and looted many treasures. Then during the seventeenth century the Puritans destroyed many images. In addition to this, rebuilding took place. For example, one of the most famous cathedrals is Salisbury, whose image is famous in John Constable's paintings. This was preceded by an eleventh century one built close by at Old Sarum. Excavations there show evidence of decorative pavements made of porphyry.

Rebuilding was also needed after fires, such as the one in 1174 at Canterbury. Here the pavements belong to the Gothic rebuilding as a result of this fire. They have not received the kind of analysis that the ones at Westminster Abbey have. Perhaps, one message that comes out of this book is that we need the English equivalent of Kim Williams's book to cover our pavements and tiles.

Christopher Norton goes into some detail about Canterbury since it is closest to the Westminster pavements. He describes how Canterbury is unique in combining pink marble and Purbeck marble, pointing out that we do not have the same wealth of material that Italy does. Purbeck marble is not strictly a marble, but a fine grain limestone, hard enough to take a polish, which comes from Purbeck in Dorset on the south coast of England. It is not surprising that Purbeck marble has also been used extensively in Westminster Abbey. The source of the pink marble has been traced to the Meuse Valley in north eastern France. Like many references to the wide area from which the materials in the Westminster pavements came (and indeed the people working on them) one can only wonder at the international communications and transport 800 years ago when most people did not move more than a mile or so from their village or town.

The Westminster Abbey pavements, while constructed by Cosmati craftsmen, are sufficiently unique to cause many authors of papers in this book to prefer the term opus sectile or "cut work," which many others see as including Cosmati work. So Norton says that the magnificent geometric mosaic to the west of St Thomas à Becket's shrine in Canterbury is the closest we have to the Cosmati pavement in Westminster Abbey, even though its ancestry is the same as the French and German opus sectile and he describes some of the links to the north eastern European pavements. He then describes why availability of materials (including lack of marble) and the craftsmanship available in making ceramic tiles meant a different approach to pavements in England. I am familiar with the ones in St Albans Abbey since I live close by and regularly go to the lunchtime organ concerts. They are indeed of high quality and we must not lose sight of our heritage in England, which is different from, and no less important than, the marvels of marble pavements in southern Europe.

This skill in making tiles also puts in context Henry III's and the Abbott of Westminster's need to go to the Mediterranean to find craftsmen in order to accomplish something different. He ends by setting the scene for the next paper, the politics of why Henry wanted something special. The extensive bibliography contains a wealth of references to a wide range of pavements and tiles in Europe as well as England. 


\section{"Westminster Abbey and the Cosmati Pavements in Politics, 1258-1269," by David Carpenter}

Many books on pavements and floor tiles consider technology or geometry without covering the reasons as to how or why they came into being. Perhaps they do not have the unique history that the Westminster Abbey pavements do. This paper brings the reasons behind the construction of the pavements and brings them to life with the struggle they went through in the context of the politics of the times.

The thirteenth century was a time when the politics of church and state were in high turmoil. In 1215 King John had been forced by the Barons to sign Magna Carta. Henry III reigned from 1216 and was in the similar position of not being an absolute monarch, despite his belief that he was ruling with the divine right of kings, perhaps not helped by his being only nine when he ascended the throne. This was the century when the mother of parliaments was in its infancy. Moreover, Henry has his own agenda for the rebuilding of Westminster Abbey, aligning himself with the icon of St Edward the Confessor. There had been civil war and the king was subject to the authority of the Baronial Council, although their hold varied in severity, this restricted his ability to obtain money for his work on the Abbey. One can only marvel that so much was achieved, not least the construction of something as complex as the Great Pavement.

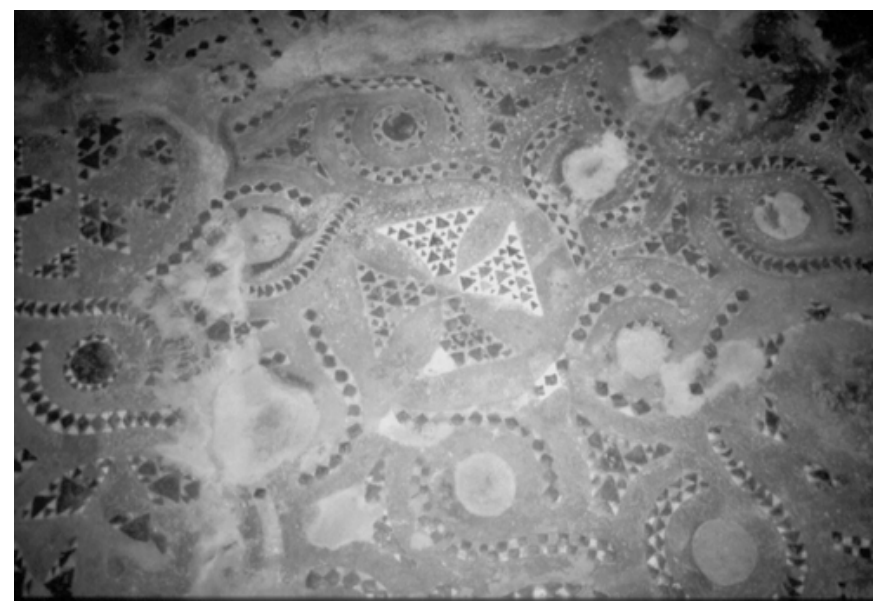

Detail of the pavement in the tomb of Edward the Confessor. Photograph @John Sharp

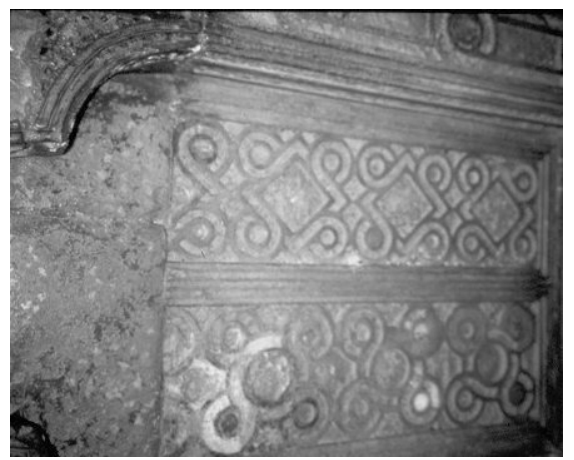

The quincunx designs on the tomb of Edward the Confessor. Photograph $@$ John Sharp 
Comparing that time with today's secular society, it is hard to see how a saint can be such a force in defining how such work could be carried out. But Henry saw St Edward as "a saint of mighty power," supporting him in this life and standing ready to guide him to the next. One might say, Henry was more concerned with his soul that his role in life and to this end claimed St Edward as his own and hence spent a considerable effort in reconstructing the Abbey.

In today's world of political spin (especially in the United Kingdom) one could be forgiven for thinking that it had been invented recently with the advent of mass communication. The baronial council was manipulating the king so that he was forced to beg them to carry out his wishes rather than he command them. David Carpenter makes it clear that today's politicians could learn a lot from history. So while Henry was claiming Edward for himself, they made sure they got a piece of the action. Edward the Confessor would protect the kingdom as well as the king and the members of the council were not adverse to making sure their presence was noted. So their armorial shields are placed in the wall arcades of the aisles flanking the liturgical choir.

The timetable for reconstruction was not just driven by money, there were symbolic reasons too. Edward's shrine had been moved once before defining his greatest feast day 13 October, which was a Sunday in 1163. Henry freed himself to a large extent from the control of the baronial council by 1263 . He now had a target date for the translation of the shrine 13 October 1269, which was also a Sunday. Such symmetry and calculated days might seem coincidental, but David Carpenter provides evidence that there was a great deal of credence placed on this.

Apart from this date setting the agenda, Henry was getting old and was concerned for his salvation. He was also hoping for help from Edward the Confessor with the disorder in the kingdom and his financial difficulties (added to which, he wanted to send his son Edward on a crusade). So 1269 was to be the greatest event of his reign and he knew he was "meant" to live that long. The reconstruction work was completed, including the pavement in 1268, but the event itself did not go off well. Quarrels broke out during the ceremony and the bishops did not form a procession behind the body of Edward the Confessor. This carried on afterwards, so while Henry may have gained some prestige, the remaining three years of his reign were not smooth.

This story could have been a piece of fiction, but then truth is stranger than fiction. It does make good reading though, but with one thing missing: why the complex Great pavement and Cosmati work around Edward's shrine? Following the extensive bibliography, the next paper fills in this background.

\section{"The Context and Fabric of the Westminster Abbey Sanctuary Pavement," By Richard Foster}

Richard Foster's book on the pavement [1991] was the one that first interested me in the subject. It makes a companion book for these papers, explaining the reasons why the pavement was built and providing a great more detail on the structure and symbolism of it. This paper extends the book. In its description, he prefers the term opus sectile rather than Cosmati, seeing the former as a broader term and contrasting it with the technique of mosaic, where the pieces are the same size.

He fills in the background on the why and how Cosmati work came to Westminster rather than the adopting the local technique of glazed tiling described above. The largest stretch of undisturbed Cosmati pavement is in the crypt of Anagni cathedral. Richard de Ware arrived at Anagni in 1260 for papal confirmation as the new abbot of Westminster. The Cosmati work there had been completed around 1230 and he was obviously impressed enough to bring back 
workmen and marble at his own expense to Westminster. The master was probably Petrus Oderisius, who created Pope Clement IV's tomb in Santa Maria in Gradi.

Having established this, he goes on to support Christopher Norton's ideas of the tradition of using opus sectile work for shrines and then gives a brief discussion of the geometry. This goes very little beyond the proportion $1: \sqrt{ } 2$ and its relationship to the doubling of the square. He stresses, perhaps too strongly, that the two squares are 17 and 12 roman feet (17/12 is familiar as an approximation to $\sqrt{2}$, just as $22 / 7$ is an approximation to $\pi$ ). When I met him after the conference and asked him about the geometry of the pavement he was shy of discussing it, perhaps seeing me as the type of "sacred geometer" that gives the study of such a geometry a bad name. I still do not see that has been enough study of the geometric detail of the Great Pavement and the quincunx design on and around Edward the Confessor's tomb related to the wider use of such designs in Cosmati work.

The middle part of his paper is concerned with the identification of the materials. It is set in Purbeck marble, as described in Christopher Norton's paper. There are various other stones brought from Italy. Identification of many of the materials has been helped by a set of marble samples collected by the Roman lawyer Faustino Corsi which he gathered and catalogued from the decorative marbles in Rome in 1825. Corsi's collection of 1000 samples is now in the University Museum in Oxford.

As well as cut stone there are smaller amounts of opaque and transparent glasses. The analysis of the opaque ones shows the closest match (with a high sodium and low potassium content) is found to be with enamels at Limoges. The transparent ones (with high potassium and low sodium) are typical of north western Europe. This again shows the wide international communication taking place at this time.

The Great Pavement is unique in having an inscription. Richard Foster only goes into this briefly since his book on the pavement [1991] details it at length. This is also the best place to go for the cosmological significance of the pavement as whole. He is concerned here with the chemical analysis of the remaining letters and shows that they were probably cast at the same Royal Foundry that cast steelyard weights, the standards issued to merchants by the crown.

The latter part of the paper is a chronology of the various restorations it has undergone in past 750 years. It is remarkable that so much has survived. (The next paper, by Nicholas Durnan brings this up to date.) There are over 50 notes and references.

"The Condition and Conservation of the Cosmati Pavements at Westminster Abbey," by Nicholas Durnan

In 1997-98 Nicholas Durnan directed a survey, practical trials, and remedial work on the pavements. The Great Pavement was particularly difficult to assess since you need to look down from the triforium to see it as a whole, but be down on your knees to get close enough to appreciate the intricate detail and workmanship.

In the Great Pavement, the team was able to identify different geological materials, some dating from around 1268 as described by Richard Foster. Another two groups were from 1660-62 repairs and some late seventeenth/early eighteenth century ones and then the 1867-8 work by Gilbert Scott, which could be differentiated by mechanical cutting. Mortar varies from original hard opus signinum (with Roman Brick dust) with later soft lime motor and Scott's Portland Cement. 
For Edward the Confessor's shrine area, much 1268 material is present with later repairs and some early twentieth-century, poorly worked, reconstruction.

The condition of the pavement was remarkable considering its date. It was very dirty (especially from the covering carpet) with some discolouring of the mortar. Although there are parts missing, most of the stones are still original but some are more durable than others. There was no rising dampness, but condensation has played a part in some places. The shrine area was similarly dirty, but the protection of the sawdust, linoleum and wood covering of the 1930s had not caused any deterioration of the floor. Previous cementing and dirt detracted from showing the full beauty and there were thousands of pieces missing.

Causes of decay in both cases showed condensation is the worst enemy with failure of the mortar having meant loss of the inscription and some pieces of stone and glass. In the shrine, some rising damp and condensation is causing the Purbeck marble to decay.

Trial cleaning and repairs was undertaken in 1998 including fixing loose small pieces with wax protection of stone and lime mortar surfaces. This included estimating the cost of long term repairs. A measured drawing was made, a copy of which is in a folding plate at the end of the book together with another of a photograph. Conservation was supported by photography as well as copious documentation.

\section{"The Inscriptions in the Sanctuary Pavement at Westminster, "by David Howlett}

The first sentence of David Howlett's paper describes its ideas:

The text of the inscription on the Westminster Sanctuary pavement belongs in the finest tradition of Biblical writing concerned with cosmology and Creation, a tradition that makes complex use of numeric symmetry and plays word games with numbers and ratios.

To show the kind of ways he works, first you must know that the Fibonacci numbers are approximations to the Golden Section (which Howlett most frequently calls by the ancient Greek term, "division in extreme and mean ratio"). Usually when such games are played, suitable words are found in the sentence according to the numeric ratio of their position to the total number of words. For instance, if I take the title of his paper with its eight words, the fifth word in the title, Sanctuary, should be significant, because it holds roughly the Golden Section position in the title (the ratio 8:5 is Golden Section). (I am sure that Howlett did not employ this technique in his title; if I were deliberately employing this technique, I would have made pavement the prominent word).

I am sceptical of anyone playing such games with numbers, although I am aware that this has been done in previous times and still is with books that purport to show hidden meaning, for example the recent spate of books about the so-called "Biblical code" [Drosnin 1998; Washburn 1998]. It is easy to be mislead and shocked or surprised, and this makes it possible to play on the superstitions of others and/or deceive oneself. I read the paper in a very sceptical frame of mind since, as I said when I wrote the original conference review, I had reservations about David Howlett's talk and said I would need a fully written paper to be fully convinced of his theory, which seemed less plausible in the light of day than it did during the talk. Having seen the paper, I feel it sticks out like a sore thumb amongst the other scholarship.

The paper can be seen as two parts, the first about word games using text from the Bible and the second about the inscription on the pavement. The first part takes up about two thirds of the paper and is there to justify that the Biblical texts "inspired a tradition of cosmological poetry in 
these islands from the seventh century to the seventeenth." The type of games he plays with the Biblical text (for which he uses Hebrew, Greek and Latin versions) is juggling with Fibonacci numbers in the way I described at the beginning of the review of this paper. Moreover, his examples belong to a different time frame despite his suggestion that they provide the tradition for the wording of the inscription. My reason for saying this is because he does not show any correspondence with the inscription. I am proposing to review and analyse these in greater detail in a later issue of the Nexus Network Journal. So I will now move on to the inscription on the pavement.

The inscription. The inscription given in Richard Foster's book is:

+XPI: MILLENO: BIS: CENTENO: DUODENO: CUM: SEXAGENO: SUBDUCTIS: QUATUOR: ANNO:

TERTIUS: HENRICUS: REX: URBS: ODORICUS: ET: ABBAS: HOS: COMPEGERE: PORPHYREOS: LAPIDES:

SI: LECTOR: POSITA: PRUDENTER: CUNCTA: REVOLVAT: HIC: FINEM: PRIMI: MOBILIS: INVENIET:

SEPES: TRIMA: CANES: ET: EQUOS: HOMINESQUE: SUBADDAS: CERVOS: ET: CORVOS: AQUILAS: IMMANIA: CETE: MUNDUM: QUODQUE: SEQUENS: PREEUNTIS: TRIPLICAT: ANNOS:

\section{SPERICUS: ARCHETIPUM: GLOBUS: HIC: MONSTRAT: MACROCOSMUM:}

[Foster 1991: 80]

In my original review I stated that Howlett said there are 364 characters and I had only counted 351. In the above there are 351, and in Howlett's text there are 354, so I either misheard or misread my notes. The three-character discrepancy is that Howlett begins with XPISTI compared with Foster's XPI. The only other mention of the inscription in this book is in Richard Foster's paper, so this does not help in getting to the truth of the original inscription. Since only seven characters remain in situ we have to rely on documentary evidence, and Foster [1991] describes the sources. The earliest one is Flete's History of Westminster Abbey compiled in 1443, of which only 16 of the probable 56 folios exist in Dublin (but luckily a copy was made and kept amongst the muniments of Westminster Abbey). This records the inscription as beginning with CRSTI, but because there are known copying errors from a comparison of the original 16 pages with the Westminster Abbey version it is unreliable as a copy. The second source is also a manuscript: Richard Sporley's "History of the Abbots of Westminster" which was written in 1450. Sporley was a monk at Westminster and so would have had direct access to the inscription and he uses the abbreviation XPI which also agrees with the indents of the missing letters in the pavements. There is no clue to why Howlett begins with XPISTI adding three extra characters: can it be only to juggle the numbers? The removal of three characters causes the counting Howlett uses to give different results in most cases.

Apart from adjusting the first word, he also chooses to break the second part of the inscription that falls on the circles in a different way from Richard Foster, I assume in an attempt to convert it into verse, something which I don't think it is. All he seems to show is that since it is a continuous text, breaking it into a series of lines can either be an arbitrary act or some skilled analysis of the flow of the syllables is required. He has appeared to do the former and then attempt to analyse the structure by syllables rather than the other way round. To partly illustrate his analysis, I will, however, use the outer inscription since this is at least broken up by the position of the words on the sides of the square. He counts a rhyme scheme, number of words in 
each line and number of letters. None of these yield any pattern, in fact the reverse, although he says "we see that they are constructed with a strong internal logic." Apart from the counting, he looks for order by highlighting what he calls alliteration (in bold) and rhymes (in italics):

\author{
+ Xpisti milleno bis centeno duodeno \\ cum sexageno subductis quatuor anno \\ tertius Henricus rex urbs Odoricus et abbas \\ hos compegere porphyreos lapides
}

The Concise Oxford Dictionary says that alliteration is "the occurrence of the same letter or sound at the beginning of adjacent or closely connected words (e.g., cool, calm, and collected)." So I see no alliteration, but occasional spurious similar pairs of letters or ones which are not even related and not even at the beginning of words in some cases. This adds a whole new meaning to alliteration, even allowing that we do not even know how the letters were sounded so long ago. Also given that Latin has endings that are similar, the same or a similar ending does not make a rhyme. In the marked rhyming, I was going to say that selection has been undertaken in order to make a point, but I don't see any point having been made. He tries to find a pattern in the rhyming scheme of the lines but has almost as many types of pattern as there are lines and they fall into no symmetric pattern. I would also read the third line with rhyming stress on

\title{
tertius Henricus rex urbs Odoricus et abbas
}

Having got this far, I would have expected a comparison with the ideas of the first part of the paper, but instead there are more lists of counting which seem pointless as he gives them. If you allow that he has added three extra characters and so changed the results anyway, then who knows what conclusions can be drawn about this aspect of the inscription.

Some conclusions can be drawn in a wider sense, however. One is that if you want to know about the inscription go to Richard Foster's book where a clear and logical argued description is given. Secondly, the saying " cobblers should stick to their lasts" springs to mind and that nonmathematicians should not play games with numbers. Allied to this might be that if such analysis is to have any hint of logical argument, you need to show direct or analogous relationships; in this case neither type can be drawn between the jumble of numbers in the first part which was written with the intention of showing evidence of style and the similar set concerned with the inscription.

There is not space at present to critically examine Howlett's ideas, especially those in the first part of his paper concerning Biblical texts. This will be discussed in a wider context in a future issue.

\section{“The Cosmati And Romanitas In England: An Overview, "By Paul Binski}

Paul Binski's paper is effectively divided into three parts. The first part is an introduction on the relationship of the Cosmati to the "Gothic" Westminster Abbey and a section titled "Rome and Northern Europe: the odyssey of the stones" and is very heavy going. It is packed with detail but written in a very rambling and so apparently disorganised manner. I am not a historian, so find it difficult to decode what he is trying to say. For example, he is describing the significance of "Rome" in the reconstruction of the Abbey by Henry III and hops between its meaning as "the church" or as "city which is a source of antiquities." Thankfully, the other parts are better written and directly related to the pavements and of more interest, if you are not put off by the first section. Whereas the first part is a jumble of facts and relationships, the last two parts raise many questions, not least that conflict with dates mentioned in the other papers. They are titled "Issues 
of interpretation I: The Sanctuary Pavement" and "Issues of interpretation II: The shrine and tomb of Henry III". Although the latter has been mentioned previously, its prominence here echoes the quote from Lindy Grant's introduction cited above: "the context, the interpretation and the meaning of the Westminster Cosmati pavements remain unresolved, topics for future work and discussion."

The Sanctuary Pavement. Asking questions such as, "Was the high altar also Cosmatesque?" (since the Cosmati frequently executed altars as well as pavements), makes one realise that we only see part of the picture. Because the Abbey has been altered many times in the past centuries, we can never hope to know about some things, even if they were recorded. This section gives clues to the meaning of the pavement and why it was constructed, but mostly this requires you follow the references through the notes, particularly the work of Stephen Wander. Two main ideas come across. Firstly, that the grave of Edward the Confessor in front the altar (it was later moved to behind the shrine) acted as a resting place during the construction of a "proper" tomb, as happened with Henry and Queen Eleanor of Castile. Secondly, it might have been a floor invented to have a function in the coronation ceremony. The full text give Binsky's arguments for these two hypotheses, but my conclusion is that we don't really know and it is unlikely we ever will.

The shrine and tomb of Henry III. In this section Binsky raises the questions as to whether the shrine to Edward the Confessor was completed before or after translation, and whether the pavement is primary or secondary to the shrine. It may be that the pavement being more prominent (since it is front of the altar and the shrine hidden behind it) has resulted in its taking a higher priority. He also raises the question of why Henry agreed to a lavish Cosmati pavement when he had never seen one, not having travelled to Italy.

There is much more, but again we come back to the question as to whether we will ever know the true meaning and reasoning behind it all.

\section{Conclusions}

This is a fascinating subject. We tend to look at good architecture, and art come to that, with a sense of wonder and usually judge it by our own aesthetics and that of our own time and culture. There is obviously much more to appreciate if we can see it from its own point in time and that despite knowing so much, there is much to learn and such scholarship leads to asking more questions as well as answering others. As the time between its conception and implementation lengthens, so the reasons for a particular design and its "purpose" tend to be lost. This book brings alive the background to an important part of English heritage in a way that adds to the uniqueness of an already unusual piece of Cosmati work. If you visit London, Westminster Abbey should definitely be on your list of places to visit.

Another message that comes over strongly is that more exchange needs to be made across the disciplines of art/architecture and mathematics/science. Since I am writing this in the journal devoted to the links between mathematics and architecture, then I feel that I need to make some points relevant to these links. Firstly, the geometry is neglected, although Richard Foster has made some inroads to this in his book. Partly this is because scholars feel intimidated by the tainting of the study of such geometry by the "sacred geometers," and partly by the unease with which many in the humanities feel about mathematics in general. It is not just unease, but a naïvete as well, as indicated by the inclusion of a paper on number games which by contrast seems acceptable when it has less content than might be seen to be mixed up in fringe geometry. 


\section{References}

Drosnin, Michael. 1998. The Bible Code. Touchstone.

Foster, Richard. 1991. Patterns of Thought: Tthe Hidden Meaning of the Great Pavement of Westminster Abbey. Jonathan Cape. (Out of print.)

Grant, Lindy and Richard Mortimer, eds. 2002. Westminster Abbey: The Cosmati Pavements.

Courtauld Institute Research Papers, 3. Ashgate Publishing.

Howlett, David. 1995. The Celtic Latin Tradition of Biblical Style. Dublin: Four Courts Press.

Livio, Mario. 2002. The Golden Mean: The Story of Phi, the World's Most Astonishing Number. Random House.

Malcolm, J. P. 1803-1807. Londinium Redivivium, or an Ancient History and modern description of London. 4 vols.

SHARP, JoHn. 1999. Cosmati Pavements at Westminster Abbey. Nexus Network Journal 1: 99-104.

Washburn, Del. 1998. The Original Code in the Bible: Using Science and Mathematics to Reveal God's Fingerprints. Madison Books.

WiLliams, Kim. 1997. Italian Pavements: Patterns in Space. Houston: Anchorage Press.

\section{About The Reviewer}

John Sharp has researched and taught Geometry and Art for over 20 years in Adult Education in and around London. He is the illustrator of David Wells' Penguin Dictionary of Curious and Interesting Geometry and has written his own book on modelling geometrical surfaces called Sliceforms, some of which are in the "Strange Surfaces" exhibit in the Science Museum in London. 